\title{
Biological control of Podosphaera xanthii the causal agent of squash powdery mildew disease by upregulation of defense-related enzymes
}

\author{
Yaser M. Hafez ${ }^{1 *}$, Asmaa S. El-Nagar², Abdelnaser A. Elzaawely², Said Kamel ${ }^{3}$ and Hanafey F. Maswada²
}

\begin{abstract}
Squash (Cucurbita pepo L.), one of the most important vegetable crops for human nutrition all over the world, is infected by many diseases, particularly powdery mildew caused by Podosphaera xanthii (syn. Sphaerotheca fuliginea), which is considered the most serious disease causing yield losses. This research study was conducted to investigate the role of Bacillus subtilis, Bacillus chitinosporus, Bacillus pumilus, Bacillus megaterium, Bacillus polymexa, Trichoderma harzianum, and Trichoderma viridi on squash leaves infected with $P$. xanthii under laboratory and greenhouse conditions. Results indicated that all treatments significantly inhibited the conidial germination of $P$. xanthii than the control. A significant decrease in the disease symptoms, severity, and the area under disease progress curve (AUDPC) was registered in squash plants sprayed with the tested bio-agents, particularly B. subtilis, B. pumilus, and T. harzianum. The activity of defense-related enzymes, i.e., catalase (CAT), peroxidase (POX), and polyphenol oxidase (PPO), were significantly upregulated as results of most treatments. Light and scanning electron microscopic (SEM) investigation showed that the morphological shape of $P$. xanthii was abnormal and the pathogen growth was limited in bio-agent-treated plants compared to control plants that showed dramatic infection. Bio-agent treatments significantly increased growth and yield attributes of squash plants over control. Overall, the results showed possibility of using the tested bio-agents to control squash powdery mildew disease as an alternative to fungicides' use that is harmful for human health and polluting the environment.
\end{abstract}

Keywords: Bacillus sp., Trichoderma sp., Powdery mildew, Squash, Spore germination, Antioxidant enzymes

\section{Background}

Squash (Cucurbita pepo L.) is exposed to different plant pathogens causing serious diseases and yield losses. Powdery mildew is the most serious disease that attacks squash plants and causes $30-50 \%$ of yield losses (El-Naggar et al. 2012). The causal agent of cucurbit powdery mildew disease is Podosphaera xanthii, which is one of the most important limiting factors of cucurbit production all over the world (Tanaka et al. 2017). Plant diseases are controlled by agreeable means, like resistant varieties, chemical fungicides, natural production, oils,

\footnotetext{
* Correspondence: hafezyasser@gmail.com

${ }^{1}$ EPCRS Excellence Center, Plant Pathology and Biotechnology Laboratory, Department of Agricultural Botany, Faculty of Agriculture, Kafrelsheikh University, Kafr-Elsheikh 33516, Egypt

Full list of author information is available at the end of the article
}

and biological control (Hafez et al. 2008). Control of such diseases based mainly on recommended chemical fungicides that are not healthy because of their hazardous effects on human, animals, plants, and useful organisms, as well as developing pathogen resistance (Abdel-Monaim et al. 2012). To overcome these problems, suitable control measurements and alternative safe methods, such as cheap and friendly environment control methods, are needed. Biological control methods could be considered as alternatives of chemical control. Bacillus spp. are safe and have high possibilities of disease control as they are located everywhere in nature and exhibit high thermal tolerance by forming resistant spores (Tanaka et al. 2017).

Bacillus subtilis is one of the antagonistic microorganisms that is used as a bio-control agent against soil-borne and foliar diseases (Muis et al. 2015). Bacillus spp. possesses 
antifungal activity against plant pathogens (Lee et al. 2013). Bacillus megaterium is a plant growth-promoting rhizobacteria that plays an important role in controlling plant diseases (Porcel et al. 2014). Trichoderma sp. is able to attack other fungi, due to its production of antibiotics that affect other microbes (Harman 2006). Trichoderma harzianum is an important bio-control agent for several plant diseases (Soliman et al. 2017). The upregulation or downregulation of antioxidant enzymes is correlated with resistance in several host/pathogen combinations, particularly obligate parasites, such as powdery mildew and rust diseases (Hafez et al. 2014a, 2014b; Abdelaal et al. 2014; Hafez et al. 2016; Hafez et al. 2017).

The present study aimed to investigate the efficacy of the antifungal and bacterial bio-agents to control the squash powdery mildew disease caused by $P$. xanthii under greenhouse conditions and their effects on the activity of defense-related enzymes, growth, and yield attributes.

\section{Materials and methods}

\section{Plant material and experimental design}

Squash seeds (Cucurbita pepo L., cv. Eskandarani) were sown in a clay loam soil and grown under greenhouse conditions at Sakha Agricultural Research Station, Agricultural Research Center, Egypt. The experiment was conducted in a randomly complete block design (RCBD), with three replicated plots for each treatment. Squash seeds were cultivated at spacing of $60 \mathrm{~cm}$ between plants in rows and $80 \mathrm{~cm}$ between plant rows at the rate of three seeds "per hill." The seedlings were thinned to one per hill after 15 days after sowing (DAS). Squash plants in all plots received all the recommended agricultural practices.

\section{Tested treatments}

The efficacy of the bio-agents (two fungal and five bacterial strains) comparing to the fungicide (Topas-100) for controlling squash powdery mildew disease was tested under greenhouse conditions. Bacillus subtilis, Bacillus pumilus, and Bacillus chitinosporus were previously isolated from the surface of healthy cucumber and squash leaves and identified according to Kamel (2003), while B. megaterium, Bacillus polymexa, and fungal strains (Trichoderma harzianum and Trichoderma viridi) were obtained from the Microbiology Department, Soil, Water and Environment Research Institute, Agriculture Research Center (ARC), Giza, Egypt. Trichoderma harzianum and $T$. viridi were grown on PDA medium for 10 days, then their spores and mycelial suspensions were separately prepared and adjusted to about $10^{7}$ spore $\mathrm{ml}^{-1}$ with sterilized water, using a hemocytometer slide, while B. subtilis, B. polymexa, B. pumilus, B. chitinosporus, and $B$. megaterium were separately grown in nutrient liquid medium in 250-ml flasks and kept on an orbital shaker at $150 \mathrm{rpm}$ for 3-4 days. The pellets of each bacterium were separately suspended in tap water, and number of cells was adjusted to $10^{9} \mathrm{cell} \mathrm{ml}^{-1}$, using a hemocytometer slide. For comparison with the tested bio-agents, plants were sprayed by distilled water as a negative control (C). In addition, widely used fungicide, Topas- $100^{\circ}(10.0 \%$ Penconazole " $w / v$ " [(R, S-1-(2-(2, 4-dichlorophenyl) -Q pentyl)-1H-1, 2, 4-triazole]), was sprayed, at the recommended dose of $0.25 \mathrm{ml} \mathrm{l}^{-1}$ as a positive control.

\section{Spore germination of Podosphaera xanthii as affected by tested bio-agents}

Conidial spores of squash powdery mildew were obtained from young sporulating lesions. To avoid the old unviable conidia, the lesions were gently shaken by a glass rod, and $24 \mathrm{~h}$ later (as recommended by (Godwin et al. 1987), new conidia were deposited on glass slides according to Nair et al. (1962). Slides were previously cleaned by ethyl alcohol and air dried before covering with thin smears of $2 \%$ water agar, amended with filter-sterilized culture filtrate of the tested antagonist. Slides were placed on V-shaped glass rods in sterilized Petri-dishes, containing several layers of water-moistened filter papers. Slides with conidia were incubated at $25{ }^{\circ} \mathrm{C}$ for $24 \mathrm{~h}$ under continuous light (Reifschneider et al. 1985) before microscopically examined, at $\times 100$ magnification, to determine the spore germination. Conidia were considered to have germinated if a germ tube, at least as long as the width, was produced (Menzies et al. 1991). Percentages of germination were calculated for 100 conidia on a slide. Three slides were examined for each treatment. Agar-free culture filtrate slides were used as a control treatment.

\section{Pathogenic fungal inoculation}

Natural infection with $P$. xanthii conidia, the causal agent of squash powdery mildew, was conducted under greenhouse conditions. Infected plants used as inoculum source (susceptible host Eskandarani) were uniformly inoculated by freshly collected conidia by placing heavy infected plants of squash which are sensitive to $P$. xanthii inoculation.

\section{Disease assessment}

The disease severity of squash leaves at 45 DAS was assessed as described by Descalzo et al. (1990). Nine random plants were used for each replicate. Severity of powdery mildew was estimated based on the percentage of affected leaf area. The mean of area under disease progress curve (AUDPC) for each replicate was calculated as follows (Pandey et al. 1989).

$$
\mathrm{AUDPC}=D\left[1 / 2\left(Y_{1}+Y_{k}\right)+\left(Y_{2}+Y_{3}+\ldots \ldots .+Y_{k-1}\right)\right]
$$


where $D=$ time interval; $Y_{1}=$ first disease severity; $Y_{k}=$ last disease severity; $Y_{2}, Y_{3}$, and $Y_{k-1}=$ intermediate disease severity.

\section{Biochemical assays of antioxidant enzymes}

For enzyme assays, $0.5 \mathrm{~g}$ of leaf material collected after 15 days from treatment with bio-agents were homogenized at $0-4{ }^{\circ} \mathrm{C}$ in $3 \mathrm{ml}$ of $50 \mathrm{mM}$ TRIS buffer ( $\mathrm{pH} 7.8$ ), containing $1 \mathrm{mM}$ EDTA- $\mathrm{Na}_{2}$ and 7.5\% polyvinylpyrrolidone. The homogenates were centrifuged $(12,000 \mathrm{rpm}$, $20 \mathrm{~min}, 4{ }^{\circ} \mathrm{C}$ ), and the total soluble enzyme activities were measured spectrophotometrically in the supernatant (Hafez et al. 2014a). All measurements were carried out at $25{ }^{\circ} \mathrm{C}$, using the model UV-160A spectrophotometer (Shimadzu, Japan). The enzymes' assay was tested three times. Activity of catalase (CAT) was determined spectrophotometrically according to Aebi (1984). Polyphenol oxidase (PPO) activity was determined according to the methods described by Malik and Singh (1980). Changes in the absorbance at $495 \mathrm{~nm}$ were recorded every $30 \mathrm{~s}$ intervals for $3 \mathrm{~min}$. Enzyme activity was expressed as the increase in absorbance $\mathrm{min}^{-1} \mathrm{~g}^{-1}$ fresh weight. Activity of peroxidase (POX) was directly determined of the crude enzyme extract, according to a typical procedure proposed by Hammerschmidt et al. (1982). Changes in absorbance at $470 \mathrm{~nm}$ were recorded at $30 \mathrm{~s}$ intervals for $3 \mathrm{~min}$. Enzyme activity was expressed as increase in absorbance $\min ^{-1} \mathrm{~g}^{-1}$ fresh weight.

\section{Microscopic examination}

The infected leaves, treated by the most effective bio-agents, were selected to investigate the growth status of powdery mildew fungus after $24 \mathrm{~h}$ of treatment. Control plants were microscopically observed for comparison and for any differences on the tested pathogen $P$. xanthii. For scanning electron microscopy (SEM), sections $(0.5 \mathrm{~cm})$ were taken from untreated and treated leaves. The samples were prefixed in mixture of $2.5 \%$ glutaraldehyde and baraformaldehyde at room temperature for $24 \mathrm{~h}$. The fixative was washed three times by phosphate buffer solution ( $\mathrm{pH} 7.2-7.4)$. The specimens were postfixed in osmium tetroxide ( $1 \% w / v$ in phosphate buffer $0.07 \mathrm{M}, \mathrm{pH} 7.2$ ) at room temperature for $1.5 \mathrm{~h}$. After washing with phosphate buffer solution three times, the samples were hydrated in ethanol series (30 and 50\% for $30 \mathrm{~min}$, and $70 \%$ for $24 \mathrm{~h}$ ), then dried at critical point of $\mathrm{CO}_{2}$ (Balzers CPD-020) and covered with gold $(30 \mathrm{~nm})$ in a sputter coater (Balzers SCD-040). The specimens were examined and photographed by the TESLA BS-300 electron microscope. In all processes, SEM observations and photography were carried out at Electron Microscope Unit, Fac. of Medicine, Tanta Univ., Egypt.

\section{Chlorophyll content and plant growth assessment}

Plant growth parameters were determined in the experimental plants at 60 DAS. Total chlorophyll contents, using the SPAD-501 portable leaf chlorophyll meter (Minolta Corp) for greenness measurements in the fifth apical fully expanded leaf (Yadava 1986). Average number and weight of fruits per plant were measured by harvesting fruits at marketable size. The squash fruits from each replicate of each treatment were collected twice a week, from 45 to $90 \mathrm{DAS}$, and the accumulated yield was expressed as the number and weight of fruits per plant. Leaf area was determined, using the dry weight method. The leaves of a plant were cleaned from dust and then representative 10 disks were taken, using a test tube known for its area $\left(1.76 \mathrm{~cm}^{2}\right)$. The leaf area was calculated, using the following formula:

Leaf area $=($ weight of leaves $\times 10 n) /$ weight of 10 disks

where $n=$ the area of one disk.

\section{Statistical analysis}

The data were subjected to statistical analysis by ANOVA, using wasp software (Web Agriculture Stat Package). The values presented are the means of all measurements, and comparisons of means were determined by Duncan's multiple range tests, at $P \leq 0.05$ (Gomez and Gomez 1984).

\section{Results and discussion}

Effect of tested bio-agents on conidial germination of $P$. xanthii and disease measurements of mildewed squash plants

Results presented in Table 1 indicated that all treatments significantly inhibited the conidial germination of $P$. xanthii than in the control. The highest efficiency over control (98.53\%) was recorded by B. megaterium and fungicide, followed by B. pumilus and B. polymexa (95.21 and $90.75 \%$, respectively). The disease symptoms of squash

Table 1 Effect of bio-agent treatments on conidial germination of $P$. xanthii, $24 \mathrm{~h}$ after treatment and incubation at $28 \pm 1{ }^{\circ} \mathrm{C}$

\begin{tabular}{llll}
\hline Treatments & Concentration & Germination (\%) & Efficiency (\%) \\
\hline Control & - & $64.91 \mathrm{a}$ & 0.00 \\
Fungicide & $0.25 \mathrm{ml} \mathrm{I}^{-1}$ & $0.95 \mathrm{c}$ & 98.53 \\
T. harzianum & $10^{7}{\mathrm{spore} \mathrm{ml}^{-1}}^{-1}$ & $17.24 \mathrm{~b}$ & 73.44 \\
T. viridi & $10^{7} \mathrm{spore} \mathrm{ml}^{-1}$ & $13.79 \mathrm{bc}$ & 78.75 \\
B. subtilis & $10^{9} \mathrm{cfu}$ & $11.97 \mathrm{bc}$ & 81.55 \\
B. chitinosporus & $10^{9} \mathrm{cfu}$ & $9.23 \mathrm{bc}$ & 58.05 \\
B. pumilus & $10^{9} \mathrm{cfu}$ & $3.11 \mathrm{bc}$ & 95.21 \\
B. megaterium & $10^{9} \mathrm{cfu}$ & $0.95 \mathrm{c}$ & 98.53 \\
B. polymexa & $10^{9} \mathrm{cfu}$ & $6.00 \mathrm{bc}$ & 90.75 \\
LSD 0.05 & & 15.66 & - \\
\hline
\end{tabular}

Values are means of three replicates of each treatment Means values for each parameter followed by different letters are significantly different $(P \leq 0.05)$, according to Duncan's multiple range test 


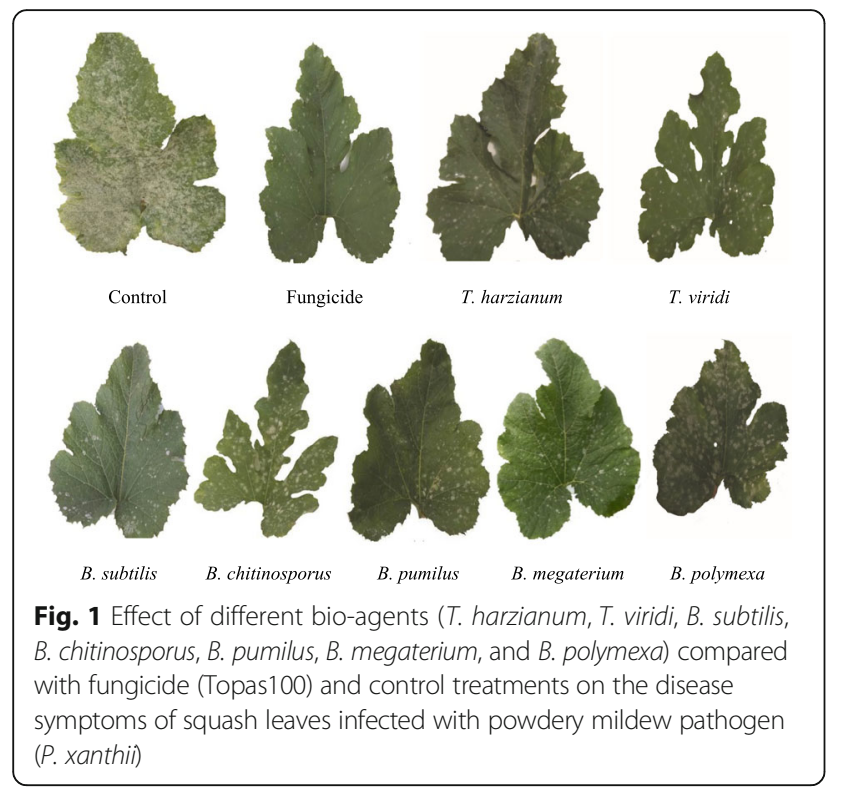

plants infected with the powdery mildew pathogen and treated with fungal and bacterial bio-agents under greenhouse conditions were suppressed and inhibited, similarly to the fungicide treatments, as compared with control (Fig. 1). Control plants showed the typical disease symptoms, as a leaf surface was covered by a visible white, talcum-like, powdery mass that composed of mycelia and conidia of the causal agent. Results presented in Table 2 revealed that treated plants, four times, with the tested bio-agents reduced area under disease progress curve (AUDPC) and disease severity (DS \%) compared with control. Maximum reduction in DS (\%) over control was found in plants sprayed with suspension of $B$. subtilis (64.72\%) and B. pumilus (64.44\%), followed by plants treated with $B$. megaterium, $T$. harzianum, $T$. viridi, and $B$. chitinosporus (56.68, 43.61, 38.79, and 33.2\%, respectively), while B. polymexa achieved the lowest reduction in DS\% compared with other bio-agents. The fungicide (Topas-100) caused considerable reduction in DS\% (62.61\%). Similarly, B. subtilis and B. pumilus were the most effective bio-agent treatments for reducing AUDPC of squash powdery mildew (225.61 and 226.87, respectively) than the control (643.54), while there was insignificant difference of AUDPC in plants treated with $T$. harzianum, $T$. viridi, and $B$. chitinosporus. Obtained results are in agreement with the findings of many researchers who demonstrated that the bio-agents that were used in this study were effective for controlling powdery mildew disease (Kamel 2003; García-Gutiérrez et al. 2013 and Tanaka et al. 2017). Previously, many studies demonstrated that Bacillus spp. and Trichoderma sp. made major contributions to the control of plant diseases, particularly powdery mildew (El-Sharkaway et al. 2014 and Sawant et al. 2017).

Gilardi et al. (2008) and El-Sharkaway et al. (2014) indicated that Bacillus sp. was used for controlling cucurbit powdery mildew. B. subtilis achieved the highest reduction of "DS \%." This reduction may be attributed to the role of $B$. subtilis as plant growth-promoting rhizobacteria (PGPR) that is widely applied to the management of many crop diseases (Liu et al. 2014). Antibiotic compounds such as chitinase enzyme can hydrolyze the cell walls of fungi; siderophores and other antibiotics can prevent the development of pathogens (Wang and Chang 1997). B. chitinosporus, B. polymexa, and B. pumilus have been shown to possess antifungal activity against the plant pathogens Fusarium oxysporum and Pythium spp. (Axelrood et al. 1996). Trichoderma sp. acted synergistically for reducing the disease severity of

Table 2 Effect of bio-agent treatments on powdery mildew disease severity (DS \%) and area under disease progress curve (AUDPC) of squash plants

\begin{tabular}{|c|c|c|c|c|c|c|}
\hline \multirow[t]{3}{*}{ Treatments } & \multicolumn{5}{|c|}{ Diseases severity (DS \%) } & \multirow[t]{3}{*}{ AUDPC } \\
\hline & \multicolumn{4}{|c|}{ Days after application } & \multirow[t]{2}{*}{$\overline{\text { Efficiency } \%}$} & \\
\hline & Zero time & 5 days & 10 days & 15 days & & \\
\hline Control & 33.24 a & $46.23 \mathrm{a}$ & $58.95 \mathrm{a}$ & 78.25 a & - & $643.54 \mathrm{a}$ \\
\hline Fungicide & $12.26 \mathrm{fg}$ & $18.13 \mathrm{ef}$ & $23.11 \mathrm{~d}$ & $27.44 \mathrm{e}$ & 64.93 & $244.31 \mathrm{fg}$ \\
\hline T. harzianum & $17.11 \mathrm{de}$ & $26.14 d$ & $33.93 c$ & $44.87 \mathrm{~cd}$ & 42.65 & $364.05 \mathrm{e}$ \\
\hline T. viridi & $22.43 \mathrm{bc}$ & $29.15 \mathrm{~cd}$ & $34.89 c$ & $46.02 \mathrm{~cd}$ & 41.18 & $391.29 \mathrm{de}$ \\
\hline B. subtilis & $10.04 \mathrm{~g}$ & $14.15 \mathrm{f}$ & $21.54 d$ & 30.83 e & 60.61 & $225.61 \mathrm{~g}$ \\
\hline B. chitinosporus & $25.24 \mathrm{~b}$ & $31.92 \mathrm{bc}$ & $38.24 \mathrm{c}$ & $49.18 \mathrm{~cd}$ & 37.15 & $429.44 \mathrm{~cd}$ \\
\hline B. megaterium & 14.66 ef & $20.92 \mathrm{e}$ & $24.02 \mathrm{~d}$ & 36.41 de & 53.46 & $277.31 \mathrm{f}$ \\
\hline B. pumilus & $9.09 \mathrm{~g}$ & $16.12 \mathrm{ef}$ & $20.93 d$ & $30.24 \mathrm{e}$ & 61.35 & $226.87 \mathrm{~g}$ \\
\hline B. polymexa & $20.52 \mathrm{~cd}$ & $29.11 \mathrm{~cd}$ & 38.01 c & $55.49 \mathrm{bc}$ & 29.08 & $442.94 \mathrm{C}$ \\
\hline $\mathrm{LSD}_{0.05}$ & 3.91 & 5.00 & 7.05 & 13.39 & - & 45.84 \\
\hline
\end{tabular}

Values are means of three replicates of each treatment

Means values for each parameter followed by different letters are significantly different $(P \leq 0.05)$, according to Duncan's multiple range test 

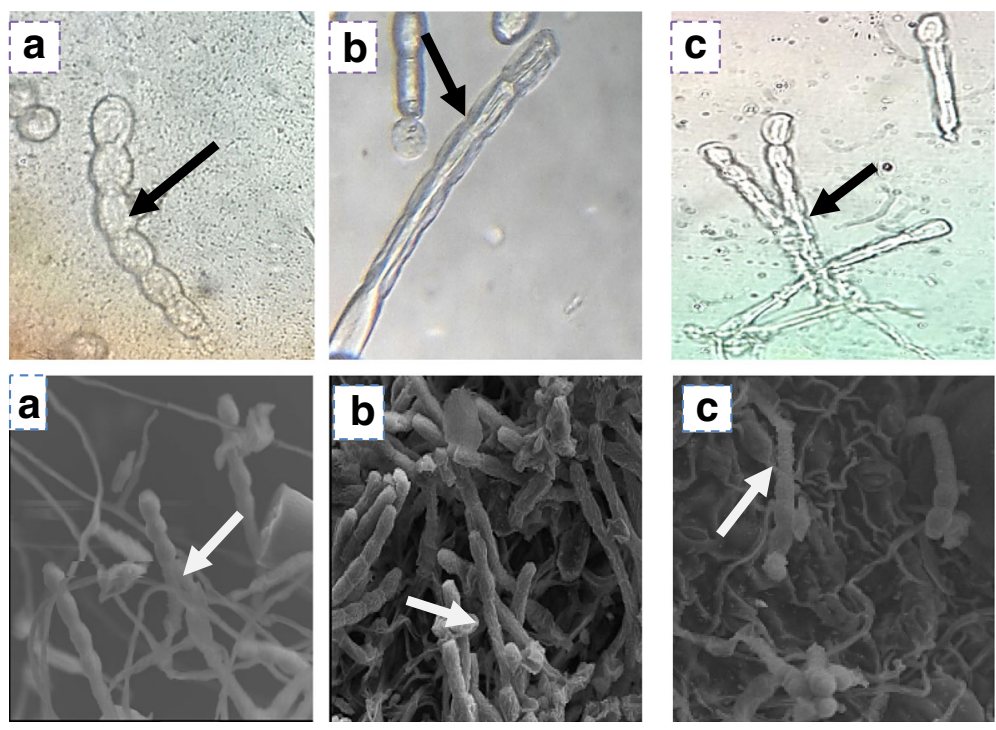

Fig. 2 Light microscopy and scanning electron microscopy (SEM) of P. xanthii on squash leaves. The growth characters of powdery mildew fungi in the control (a): leaves infected only with P. xanthii and after $24 \mathrm{~h}$ of treatment with B. subtilis (b) and T. harzianum (c)

squash powdery mildew disease by producing antifungal compounds (El-Kot and Derbalah 2011). EL-Naggar et al. (2012) found that spraying cucumber plants with T. viridi caused significant reduction in the disease of powdery mildew than in the control treatment. These results are in accordance with the results of Nada (2002) who proved that spraying plants with bio-agents was beholden effective in the programs of integrated pest management (IPM) for controlling plant diseases, especially those caused by obligate parasites such as powdery mildew. Abd-El-Moity et al. (1997) found that spraying onion and garlic plants grown under field conditions with a suspension of $T$. harzianum showed a significant reduction in incidence and severity of downy mildews.

Table 3 Effect of bio-agent treatments on chlorophyll content and growth parameters of mildewed squash plants

\begin{tabular}{llll}
\hline Treatment & $\begin{array}{l}\text { Chlorophyll content } \\
\text { (SPAD) }\end{array}$ & $\begin{array}{l}\text { No. leaves } \\
\text { plant }^{-1}\end{array}$ & Leaf area $\left(\mathrm{cm}^{2}\right)$ \\
\hline Control & $23.35 \mathrm{e}$ & $10.93 \mathrm{c}$ & $192.76 \mathrm{~g}$ \\
Fungicide & $39.71 \mathrm{~cd}$ & $12.37 \mathrm{bc}$ & $362.05 \mathrm{a}$ \\
T. harzianum & $41.99 \mathrm{c}$ & $13.56 \mathrm{ab}$ & $301.17 \mathrm{e}$ \\
T. viridi & $52.01 \mathrm{~b}$ & $11.68 \mathrm{bc}$ & $279.12 \mathrm{e}$ \\
B. subtilis & $51.19 \mathrm{~b}$ & $15.06 \mathrm{a}$ & $317.39 \mathrm{~d}$ \\
B. chitinosporus & $36.35 \mathrm{~d}$ & $11.63 \mathrm{bc}$ & $333.27 \mathrm{c}$ \\
B. polymexa & $44.26 \mathrm{c}$ & $14.87 \mathrm{a}$ & $313.09 \mathrm{~d}$ \\
B. pumilus & $59.57 \mathrm{a}$ & $12.51 \mathrm{bc}$ & $353.49 \mathrm{ab}$ \\
B. megaterium & $39.32 \mathrm{~cd}$ & $11.62 \mathrm{bc}$ & $348.18 \mathrm{~b}$ \\
LSD 0.05 & 4.99 & 2.231 & 9.011 \\
\hline
\end{tabular}

Values are means of three replicates of each treatment

Means values for each parameter followed by different letters are significantly different $(P \leq 0.05)$, according to Duncan's multiple range test
The fungicide (Topas-100) was effective against powdery mildew, as it is known that systemic fungicides are more efficient in management of many fungal diseases, including cucumber powdery and downy mildews (Abada et al. 2009).

Microscopic examination of the mildewed squash leaves treated with $B$. subtilis and $T$. harzianum

The light and SEM examination of squash leaves in control plants showed a complete fungal growth of $P$. xanthii (Fig. 2a). The fungal mycelia developed full coalescence and conidiophores in their right form. In addition, conidial chains were in natural form and size.

Table 4 Influence of biological agents on yield parameters of squash plants

\begin{tabular}{|c|c|c|c|c|}
\hline \multirow[t]{2}{*}{ Treatment } & \multirow[t]{2}{*}{ No. fruits plant ${ }^{-1}$} & \multirow[t]{2}{*}{$\begin{array}{l}\text { Fruit yield } \\
\left(\text { Kg plant }^{-1}\right)\end{array}$} & \multicolumn{2}{|c|}{$\begin{array}{l}\text { Average increase } \\
\text { over the control }\end{array}$} \\
\hline & & & Kg plant $^{-1}$ & $\%$ \\
\hline Control & $7.5 \mathrm{e}$ & $0.655 f$ & - & - \\
\hline Fungicide & $15 \mathrm{bc}$ & $1.105 \mathrm{C}$ & 0.45 & 68.7 \\
\hline T. harzianum & $16.49 \mathrm{ab}$ & $1.400 \mathrm{~b}$ & 0.75 & 113.7 \\
\hline T. viridi & $12.5 \mathrm{~d}$ & $1.340 \mathrm{~b}$ & 0.69 & 104.6 \\
\hline B. subtilis & $17.51 \mathrm{a}$ & $1.575 \mathrm{a}$ & 0.92 & 140.5 \\
\hline B. chitinosporus & $12.48 \mathrm{~d}$ & $1.070 \mathrm{C}$ & 0.42 & 63.4 \\
\hline B. polymexa & 18.53 a & $1.380 \mathrm{~b}$ & 0.73 & 110.7 \\
\hline B. pumilus & $14.0 \mathrm{~cd}$ & $1.000 \mathrm{~cd}$ & 0.35 & 52.7 \\
\hline B. megaterium & $13.0 \mathrm{~cd}$ & 0.895 de & 0.24 & 36.6 \\
\hline LSD $_{0.05}$ & 2.419 & 0.159 & - & - \\
\hline
\end{tabular}

Values are means of three replicates of each treatment

Means values for each parameter followed by different letters are significantly different $(P \leq 0.05)$, according to Duncan's multiple range test 
However, the squash leaves treated with B. subtilis (Fig. 2b) and T. harzianum (Fig. 2c) exhibited morphological anomaly such as atrophy in conidiophore and hypha of the pathogen and hydrolysis in conidia spores. Thus, the fungus can no longer develop conidiophores and conidia spores.

\section{Effect of different bio-agents on chlorophyll content and growth traits of mildewed squash plants}

All treatments significantly increased chlorophyll content, leaf area, and number of leaves plant ${ }^{-1}$ compared with control plants (Table 3). The highest chlorophyll content was observed in plants treated with $B$. pumilus (59.57), followed by $T$. viridi (52.01) and B. subtilis (51.19). However, significant differences in chlorophyll content were not found among plants treated with $T$. harzianum, B. chitinosporus, B. megaterium, and fungicide (Topas-100). Number of leaves of plant ${ }^{-1}$ greatly increased in plants treated with B. subtilis, B. polymexa, and $T$. harzianum (15.06, 14.87, and 13.56, respectively) compared with the untreated control plants (10.93). Insignificant differences in number of leaves of plant ${ }^{-1}$ were found in plants treated with $T$. viridi, $B$. chitinosporus, $B$. pumilus, $B$. megaterium, and fungicide; the maximum leaf area was obtained by the fungicide and $B$. pumilus. The improvement of plant growth parameters was due to B. subtilis as a PGPR that actively colonized plant roots by possessing three essential roles for the plant: as bio-fertilizer, bio-stimulant, and bio-protectant (Karlidag et al. 2013).

\section{Impact of bio-agents on yield parameters of mildewed squash plants}

As shown in Table 4, the mean number of fruit plant ${ }^{-1}$ significantly increased in mildewed plants sprayed with $B$. polymexa and B. subtilis reaching 18.53 and 17.51 fruit

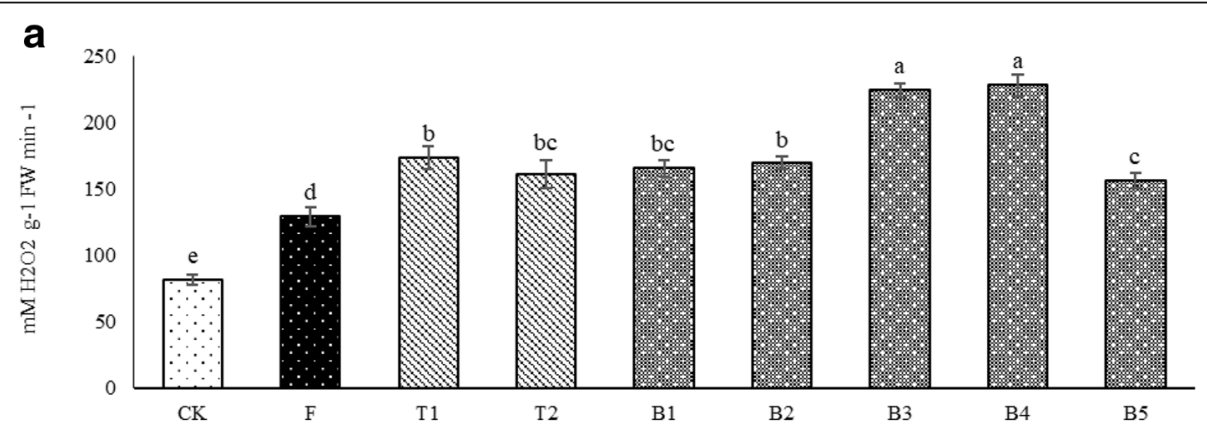

b
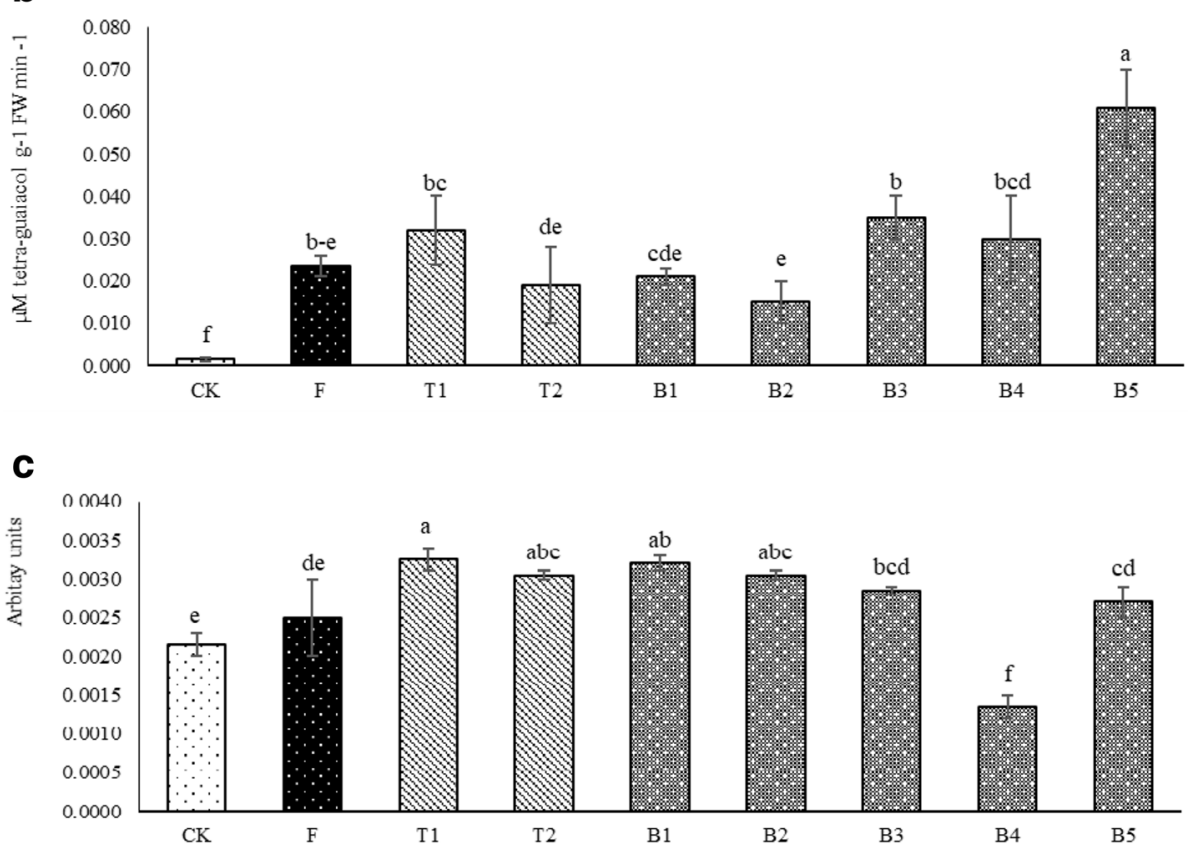

Fig. 3 a Activities of catalase (CAT), $\mathbf{b}$ peroxidase (POX), and $\mathbf{c}$ polyphenol oxidase (PPO) enzymes in squash leaves infected with powdery mildew after $24 \mathrm{~h}$ of treatments with bio-agents. CK, control; $F$, fungicide (Topas-100), $T_{1}$, Trichoderma harzianum; $T_{2}, T$. viridi; $B_{1}$, Bacillus subtilis; $B_{2}, B$. chitinosporus; $\mathrm{B}_{3}$, B. pumilus; $\mathrm{B}_{4}, \mathrm{~B}$. megaterium; and $\mathrm{B}_{5}$, B. polymexa 
plant $^{-1}$, respectively, compared with the untreated plants (7.5 fruit plant ${ }^{-1}$ ). The fungicide (Topas-100) recorded 15 fruit plant ${ }^{-1}$. Similarly, all treatments markedly increased fruit yield per plant than the control. Among the tested bio-agents and fungicide, mildewed plants treated with B. subtilis showed the highest fruit yield $\left(1.575 \mathrm{~kg} \mathrm{plant}^{-1}\right)$, with an average increase of $140.5 \%$ over control, followed by $T$. harzianum (1.40 kg plant $\left.{ }^{-1}\right), B$. polymexa (1.38 kg plant $\left.{ }^{-1}\right)$, and T. viridi (1.34 kg plant $\left.{ }^{-1}\right)$, with an average increase of $113.7,110.7$, and $104.6 \%$, respectively, over control. Wartono et al. (2015) showed that usage of B. subtilis could suppress leaf blight of rice by $21 \%$ and had the potential to increase yield up to $50 \%$. The enhancement of squash fruit yield in response to application of the bio-agents and fungicide may be attributed to biological activity mechanisms in suppressing the fungal pathogen and reduction of disease severity (Cardwell et al. 1997).

\section{Effect of bio-agents on the activity of defense-related enzymes in mildewed squash plants}

Results illustrated in Fig. 3 revealed that the tested bio-agents and fungicide (Topas-100) significantly upregulated the activity of defense-related enzymes compared with untreated plants. The highest level of CAT activity was recorded in plants treated with $B$. pumilus and $B$. megaterium, followed by T. harzianum, B. chitinosporus, $B$. subtilis, $T$. viridi, $B$. polymexa, and then fungicide, while the highest level of POX activity was recorded when squash plants were treated by $B$. polymexa, followed by $B$. pumilus. PPO activity significantly increased in all tested treatments, particularly $T$. harzianum, compared with control, except the treatment with B. megaterium. These results are in agreement with the results of El-Sharkaway et al. (2014) who found that treatment of cucumber plants with bio-agents led to activation of antioxidant enzymes such as peroxidase and polyphenol oxidase, and significantly decrease the disease severity of downy and powdery mildew in cucumber plants. Resistance might be correlated to the production of oxidative enzymes in the treated healthy and infected plant tissues (El-Sharkaway et al. 2014; Hafez et al. 2016 and Hafez et al. 2017).

\section{Conclusions}

The present study concluded that the bio-agent (Bacillus spp. and Trichoderma sp.) could significantly reduce the disease severity of powdery mildew in squash plants, caused by Podosphaera xanthii, with stimulating growth and yield attributes in comparison to control. However, the mechanism of the bio-agent role in reducing disease severity could be attributed to upregulation of defense-related enzymes (CAT, POX, and PPO).

\section{Acknowledgements}

The authors would like to thank colleagues at Plant Pathology and Biotechnology Lab. (Accredited according to ISO/17025) and EPCRS Excellence Centre (Certified according to ISO/9001, ISO/14001 and OHSAS/18001), Department of Agricultural Botany, Faculty of Agriculture, Kafr-Elsheikh University, Kafr-Elsheikh, Egypt.

\section{Funding}

Funding is by EPCRS Excellence Center and authors.

Availability of data and materials

All data and materials are available.

Authors' contributions

All authors read and approved the final manuscript.

Ethics approval and consent to participate

Ethics committee approved the research article and all authors agree (consent) to participate in this research article.

Consent for publication

All authors participated in the work and Consent for publication.

Competing interests

The authors declare that they have no competing interests.

\section{Publisher's Note}

Springer Nature remains neutral with regard to jurisdictional claims in published maps and institutional affiliations.

\section{Author details}

${ }^{1}$ EPCRS Excellence Center, Plant Pathology and Biotechnology Laboratory, Department of Agricultural Botany, Faculty of Agriculture, Kafrelsheikh University, Kafr-Elsheikh 33516, Egypt. ²Department of Agricultural Botany, Faculty of Agriculture, Tanta University, Tanta, Egypt. ${ }^{3}$ Plant Pathology Research Institute, Agricultural Research Center, Giza, Egypt.

Received: 20 February 2018 Accepted: 27 June 2018

Published online: 16 July 2018

\section{References}

Abada K, El-Alim AA, Abd-Elbacki A, Ashour A (2009) Management of pea powdery mildew disease using some resistance inducing chemicals and systemic fungicides. Egypt J Phytopathol 37:95-104

Abdelaal AA, Hafez YM, Adel Samar M, Youseef WA, Badr MM (2014) Biochemical, histological and molecular changes in some Egyptian wheat varieties infected with stripe rust (Puccinia striiformis f.sp. tritici). Egyptian J Biol Pest Cont 24(2):421-429

Abd-El-Moity T, Hanna A, Abdel-Megid M (1997) Biological control of downy mildew and purple blotch diseases of onion and garlic under field conditions. Proc $8^{\text {th }}$ Cong Egypt Phytopathol Soc:227-242

Abdel-Monaim M, Abdel-Gaid M, Armanious H (2012) Effect of chemical inducers on root rot and wilt diseases, yield and quality of tomato. Int J Agric Sci 7:211-220

Aebi H (1984) [13] Catalase in vitro. In methods in Enzymology (Packer, L., Ed.), Vol. 105. Academic Press, Orlando, pp 121-126

Axelrood PE, Clarke AM, Radley R, Zemcov SJV (1996) Douglas-fir root-associated microorganisms with inhibitory activity towards fungal plant pathogens and human bacterial pathogens. Can J Microbiol 42(7):690-700

Cardwell K, Schulthess F, Ndemah R, Ngoko Z (1997) A systems approach to assess crop health and maize yield losses due to pests and diseases in Cameroon. Agric Ecosyst Environ 65(1):33-47

Descalzo R, Rahe J, Mauza B (1990) Comparative efficacy of induced resistance for selected diseases of greenhouse cucumber. Can J Plant Pathol 12(1):16-24

El-Kot G, Derbalah A (2011) Use of cultural filtrates of certain microbial isolates for powdery mildew control in squash. J Plant Prot Res 51(3):252-260

El-Naggar M, El-Deeb H, Ragab S (2012) Applied approach for controlling powdery mildew disease of cucumber under plastic houses. Pak J Agric: Agric Eng Vet Sci (Pakistan) 28(1):54-64

El-Sharkaway MM, Kamel SM, El-Khateeb NM (2014) Biological control of powdery and downy mildews of cucumber under greenhouse conditions. Egypt J Biol Pest Control 24(2):407 
García-Gutiérrez L, Zeriouh H, Romero D, Cubero J, Vicente A, Pérez-García A (2013) The antagonistic strain Bacillus subtilis UMAF6639 also confers protection to melon plants against cucurbit powdery mildew by activation of jasmonate- and salicylic acid-dependent defence responses. Microb Biotechnol 6(3):264-274

Gilardi G, Manker D, Garibaldi A, Gullino M (2008) Efficacy of the biocontrol agents Bacillus subtilis and Ampelomyces quisqualis applied in combination with fungicides against powdery mildew of zucchini. J Plant Dis Protect 115(5):208-213

Godwin J, Mansfield J, Darby P (1987) Microscopical studies of resistance to powdery mildew disease in the hop cultivar Wye Target. Plant Pathol 36(1):21-32

Gomez KA, Gomez AA (1984) Statistical procedures for agricultural research. Wiley, New York

Hafez YM, Abdelaal KA, Badr MM, Esmaeil RA (2017) Control of Puccinia triticina the causal agent of wheat leaf rust disease using safety resistance inducers correlated with endogenously antioxidant enzymes up-regulation. Egypt J Biol Pest Cont 27(1):1-10

Hafez YM, Abdelaal KA, Eid ME, Mehiar FF (2016) Morpho-physiological and biochemical responses of barley plants (Hordeum vulgare L.) against barley net blotch disease with application of non-traditional compounds and fungicides. Egypt J Biol Pest Control 26(2):261-268

Hafez YM, Bayoumi YA, Pap Z, Kappel N (2008) Role of hydrogen peroxide and Pharmaplant-turbo against cucumber powdery mildew fungus under organic and inorganic production. Int J Horticultural Sci 14(3):39-44

Hafez YM, Mourad RY, Mansour M, Abdelaal KA (2014a) Impact of non-traditional compounds and fungicides on physiological and biochemical characters of barely infected with Blumeria graminis f. sp hordei under field conditions. Egypt J Biol Pest Control 24(2):445-453

Hafez YM, Soliman NK, Saber MM, Imbabi IA, Abd-Elaziz AS (2014b) Induced resistance against Puccinia triticina, the causal agent of wheat leaf rust by chemical inducers. Egypt J Biol Pest Control 24(1):173-181

Hammerschmidt R, Nuckles E, Kuć J (1982) Association of enhanced peroxidase activity with induced systemic resistance of cucumber to Colletotrichum lagenarium. Physiol Plant Pathol 20(1):73-82

Harman GE (2006) Overview of mechanisms and uses of Trichoderma spp. Phytopathology 96(2):190-194

Kamel SM (2003) Antagonistic effects of some microbial inhabitants on phylloplane of squash plants towards Sphaerotheca fuliginea. M. Sc. Thesis, Fac. Agric. Tanta, Univ, Egypt, p 94

Karlidag H, Yildirim E, Turan M, Pehluvan M, Donmez F (2013) Plant growthpromoting rhizobacteria mitigate deleterious effects of salt stress on strawberry plants (Fragariax ananassa). Hortscience 48(5):563-567

Lee SY, Weon HY, Kim JJ, Han JH, Kim WG (2013) Biological control of cucumber powdery mildew by Bacillus amyloliquefaciens M27. Korean J Mycol 41(4): 268-273

Liu HX, Li SM, Luo YM, Luo LX, Li JQ, Guo JH (2014) Biological control of Ralstonia wilt, Phytophthora blight, Meloidogyne root-knot on bell pepper by the combination of Bacillus subtilis AR12, Bacillus subtilis SM21 and Chryseobacterium sp. R89. Eur J Plant Pathol 139(1):107-116

Malik CP, Singh MB (1980) Plant enzymology and histo-enzymology

Menzies JG, Ehret DL, Glass ADM, Helmer T, Koch C, Seywerd F (1991) Effects of soluble silicon on the parasitic fitness of Sphaerotheca fuliginea on Cucumis sativus. Phytopathology (USA) 81:84-88

Muis A, Djaenuddin N, Nonci N (2015) Uji virulensi beberapa isolat bakteri antagonis putative Bacillus subtilis (Ehrenberg) Cohn sebagai agens pengendali hayati penyakit tanaman jagung. Bul Pen Tan Serealia 1(1):8-15

Nada MGA (2002) Studies on antifungal activities of some Egyptian medical and aromatic plants. Ph.D. Thesis, Fac. Agric., Zagazig Univ., Zagazig, p 163

Nair, K.R.; Sanaslvan and A.H. Ellingboe (1962). A method of controlled inoculations with condiospores of Erysiphe graminis var. Tritici Phytopathology 52: 417

Pandey HN, Menon TCM, Rao MV (1989) A simple formula for calculating area under disease progress curve, vol 2, pp 38-39

Porcel R, Zamarreño ÁM, García-Mina JM, Aroca R (2014) Involvement of plant endogenous ABA in Bacillus megaterium PGPR activity in tomato plants. BMC Plant Biol 14(1):36

Reifschneider FJB, Boitexu LS, Occhiena EM (1985) Powdery mildew of melon (Cucumis melo) caused by Sphaerotheca fuliginea in Brazil. Plant Dis 69:1069-1070

Sawant IS, Wadkar PN, Ghule SB, Rajguru YR, Salunkhe VP, Sawant SD (2017) Enhanced biological control of powdery mildew in vineyards by integrating a strain of Trichoderma afroharzianum with sulphur. Biol Control 114:133-143
Soliman HM, El-Metwally M, Mouneer B (2017) Integration of the three bioagents Trichoderma harzianum, T. viride, or yeast combined with compost in Management of Wilt Disease of pea plant and improving yield. Egypt J Biol Pest Control 27(2):261-269

Tanaka K, Fukuda M, Amaki Y (2017) Importance of prumycin produced by Bacillus amyloliquefaciens SD-32 in biocontrol against cucumber powdery mildew disease. Pest Manag Sci 73:2419-2428

Wang SL, Chang WT (1997) Purification and characterization of two bifunctional chitinases/lysozymes extracellularly produced by Pseudomonas aeruginosa K187 in a shrimp and crab shell powder medium. Appl Environ Microbiol 63(2):380-386

Wartono W, Giyanto G, Mutaqin KH (2015) Efektivitas formulasi spora Bacillus subtilis B12 sebagai agen pengendali hayati penyakit hawar daun bakteri pada tanaman padi. Penelitian Pertanian Tanaman Pangan 34(1):21-28

Yadava UL (1986) A rapid and nondestructive method to determine chlorophyll in intact leaves. HortScience 22:1449-1450

\section{Submit your manuscript to a SpringerOpen ${ }^{\circ}$ journal and benefit from:}

- Convenient online submission

- Rigorous peer review

- Open access: articles freely available online

- High visibility within the field

Retaining the copyright to your article

Submit your next manuscript at $>$ springeropen.com 